Article

\title{
Exploring the Coordination Mechanism for Public Housing Supply with Urban Growth Management: A Case Study of Chongqing, China
}

\author{
Wei Wang ${ }^{1}$ and Yuzhe $\mathrm{Wu}^{2, *}$ \\ 1 Business School, Zhejiang University City College, Hangzhou 310015, China; wangw@zucc.edu.cn \\ 2 School of Public Affairs, Zhejiang University, Hangzhou 310058, China \\ * Correspondence: wuyuzhe@zju.edu.cn
}

Received: 22 April 2020; Accepted: 13 May 2020; Published: 15 May 2020

check for updates

\begin{abstract}
While urbanization acts as an engine of economic growth, rising inequality and exclusion within cities derails development progress. In the past 30 years, the population in China has converged to large-scale cities, which brought a severe housing issue, not least for migrants. In order to relieve the tension between the increasing demand for housing and the scarcity of urban resources, research on housing policy in response to urban growth is a matter of cardinal significance. This paper made an effort to explore the mechanism of public housing policies coordinated with urban growth management. Taking Chongqing City as the study area, the system dynamics model was adopted in exploring the coordination mechanism. The impact of the two policies were simulated, including the urban population control and public housing supply. The results indicated that the combined policy could more effectively cope with the possible urban housing crisis under the long-term trend, and promote urban inclusive growth. Meanwhile, the starting time of intervention also has a significant impact on the policy effect. This study shares China's experience and provides reference for other developing countries to pursue socio-economic sustainability in the process of urbanization.
\end{abstract}

Keywords: urbanization; affordable housing; urban growth control; system dynamics; policy simulation

\section{Introduction}

Urbanization has been one of the most significant driving forces of recent global development and acted as an engine of economic growth. But while urbanization is moving the global economy forward, rising inequality and exclusion within cities can derail development progress [1,2]. In this context, the international community has acknowledged the need to create more livable, inclusive and sustainable cities, and to make sure that people can reap the benefits of urbanization.

In the past 30 years, the rapid economic growth in China has boosted the development of cities, both in terms of the number of cities and urban population. The number of cities increased from 193 in 1978 to 668 in 2018, meanwhile the urban population increased from 190 million to 831 million. It is found that the development speed of large-scale cities is significantly faster than that of small-scale cities, and the population is converging to large-scale cities [3]. The rapid growth of population large-scale cities brings about a severe problem, that is, the housing issue of new arrivals. The migrant workers from rural to urban areas and the farmers "brought into the city" with the expansion of urban built-up areas constitute the main source of housing demand in large cities [4]. Internationally, the process of urbanization is often accompanied by the emergence of slums [5]. To deal with the housing problem in the process of urbanization requires farsighted policies in urban growth management.

In 1980s, China's urban development was orientated to be in equilibrium, which was elaborated as the urbanization strategy of "strictly controlling large cities and actively developing small cities". 
The growth control of large cities included both spatial resources and population scale. Benefited by the public ownership of land, the control of spatial resources in land planning is relatively easy to achieve, while the control of population scale, which mainly depended on the household registration system, was difficult to achieve (if not impossible) [6,7]. The contradiction between the restriction of spatial resources dominated by planning system and the demand of housing land for population growth led by market system posed the urban planning in a dilemma [8]. In recent years, urban growth management strategy has been turned around to comply with the basic laws of urban development [9].

The rapid development of cities is accompanied by the decrease of housing affordability, especially in large cities [10]. Since the beginning of the 21st century, the construction of a large number of public housing in China has played an important role in solving the housing difficulties of low-income families and accelerated urban development [11]. On the one hand, the migrant workers who are resettled by public housing have undertaken the hard work and ensured the normal operation of the basic functions of cities. On the other hand, the population surge challenges the urban infrastructure and public services, which brings diseases, crimes, crowding and other problems to the urban development. However, in the current regulatory framework, the adjustment of urban growth management mainly depends on the revision of planning, but urban planning and management has not yet correspondingly taken the responsibility for affordable housing [4].

From the perspective of multi-player game in housing market, Lv and Chen unfolded the debates on the interactive relationship among various types of housing in China and argued for breaking the barrier of mutual conversion between commodity housing and public housing [12]. To make further efforts, Yu et al. utilized the econometric model to test the crowding-out effect between them, and found that it was not significant in the research area [13]. Based on the gravity model, Mao and Wang examined the impact of public housing on the inter-provincial population flow and the empirical results showed that the supply of public housing had a positive impact on population mobility [14]. A theoretical analysis framework was established to explore the mechanism of public housing supply on urban economic growth, and analyzed the changes of population and land issues in the process of urbanization in China [15]. Rich literature has put forward policy suggestions to increase the quantity and coverage of public housing supply, but there has been a lack of corresponding policy simulation.

If the supply of public housing is increased, what will be its impact on urban development? How should urban growth management strategies respond? How to coordinate the allocation of land resource and the construction of public housing? Out of curiosity about these questions, this study established an Urban Development Model to simulate the impacts of urban growth management policies and public housing supply policies. The purpose of building this model is not to predict the future supply of public housing and urban development, but to explore the impact of public housing supply policies on urban development and to find the key strategies to avoid the potential crisis. The research on the coordination mechanism for public housing policies with urban growth management is helpful to solve the fundamental problems in the process of rapid urbanization in China. At the same time, China's experience will provide reference for other developing countries to pursue socio-economic sustainability in the process of urbanization.

\section{Literature Review}

\subsection{Public Housing Supply}

Public housing supply is to ensure the right to live through the form of physical distribution, which is manifested in the government's intervention in the resource allocation process of the housing market, essentially reflecting an internal logic of interaction between urban economic growth and social integration. The studies on the public housing supply are widespread all over the world, but the perspective and opinions are quite different [16]. The research of supporting public housing supply often starts from the perspective of social integration, and argues that the lack of government intervention in the housing market will inevitably lead to the tendentious housing shortage, thus worsening the 
phenomenon of class stratification $[17,18]$. The research on the opposite side is often undertaken from the perspective of economic efficiency, which holds that public housing supply is equivalent to the competition between the government and private enterprises in the field of housing, and the negative impact of public housing on the economic system should be avoided $[19,20]$.

Since the reform of housing system was carried out in China at the end of the 20th century, scholars have made a lot of contributions to the system from the perspectives of historical evolution and its economic and social impact, which provide rich inspiration and guidance [11,21,22]. In the studies of public housing supply in China, it is repeatedly emphasized that local governments face the constraints of natural and social resources [23]. There is no doubt that the constraint of construction land is one of the important factors affecting the formulation of public housing policies [24-26].

\subsection{Urban Growth Management}

The city is the engine of economic growth, and urban growth management is a set of urban development strategy that aims to maintain a balance between efficiency and equity [27]. Kuznets believes that inequality would inevitably grow with economic development in the early stage; nevertheless, it will gradually disappear as the economic development model enters a mature stage [28]. A new upsurge in development theories at the end of the 20th century challenged this view, especially the research on developing countries. Since the 1980s and 1990s, the economy of developing countries has shown more and more strong momentum of development. However, the economic development has resulted in a growing gap between the rich and the poor, intensifying social contradictions. The consequences of deteriorating social relations may disrupt urban economic growth [29]. In order to cope with the dilemma of "growth without development", inclusive growth theory has gradually developed and has been widely concerned and applied in the field of urban management [30]. Facing the increasing wealth gap, the policy orientation of achieving economic growth by improving efficiency is gradually replaced by the new policy orientation of promoting urbanization and sustained economic growth by social integration [31].

The research on the relationship between housing and urban development took its rise in developed countries in the west. With the rise of the movement of the right to adequate housing, based on the theory of public economics and social welfare, scholars have developed many theories, such as the theory of social housing [32], the theory of welfare state [33], and the three-sector economic growth model [34], which constitute the basis of the current government intervention in the housing system and the construction of public housing policies. Glaeser established a theoretical model of the elasticity of housing supply and clearly explained the relationship between housing supply and urban economy [35]. This research was introduced to the Chinese scene, and empirical tests on the correlation between housing and city were conducted [36].

The studies interested in the impact of public housing supply on urban growth in China began to boom in the early 20th century. There are two main kinds of logic throughout the studies. One kind of research elaborated the logic of the impact of public housing supply on urban economic growth from the perspective of housing quality improvement and the transformation of urban production factors $[37,38]$. Another kind of research deconstructed the logic of public housing supply, promoting social integration from the perspective of public service equalization and identity $[7,39,40]$.

In summary, substantial numbers of scholars agree that the decline of housing affordability can cause serious economic and social problems [41-44]. However, there are different opinions on whether the supply of public housing can promote urban economic growth and social integration $[45,46]$. This study made effort on carrying out the simulation to illustrate the impact of public housing supply policies. From the perspective of system, the Urban Development Model was established to explore the mechanism of public housing policies coordinated with urban growth management. 


\section{Methods and Data Collection}

\subsection{Case Area}

Chongqing City was selected as the case area after a careful consideration. Many indicators of Chongqing, such as the GDP per capita, the proportion of three industries, the proportion of urban and rural employment, the proportion of labor force, the disposable income and expenditure of urban residents, and the urbanization rate, are close to the average level of the whole country (Table 1). In the process of administrative regional adjustment, Chongqing has been incorporated into the surrounding underdeveloped areas, forming a structure with obvious differences between the primary area and other districts. In addition, Chongqing is an area of ethnic integration with the Han nationality as the main body, and the minority population accounts for $6.7 \%$ of the permanent population, basically covering all minorities. These economic and social characteristics make Chongqing an epitome of the overall development of the whole country.

Table 1. Comparison of main economic and social indicators between Chongqing and China.

\begin{tabular}{lccccc}
\hline & \multicolumn{3}{c}{ Chongqing City } & \multicolumn{2}{c}{ China } \\
\cline { 2 - 6 } & $\mathbf{2 0 0 0}$ & $\mathbf{2 0 0 5}$ & $\mathbf{2 0 1 0}$ & $\mathbf{2 0 1 5}$ & $\mathbf{2 0 1 5}$ \\
\hline GDP per capita/yuan & 6274 & 10,845 & 27,598 & 52,322 & 50,251 \\
Proportion of three industries/\% & $16: 42: 42$ & $13: 45: 42$ & $8: 45: 47$ & $7: 45: 48$ & $9: 41: 50$ \\
Proportion of employment in three industries/\% & - & - & - & $31: 28: 41$ & $28: 30: 42$ \\
Proportion of employment between urban and rural/\% & $32: 68$ & $40: 60$ & $48: 52$ & $58: 42$ & $52: 48$ \\
Registered unemployment rate/\% & 3.5 & 4.12 & 3.9 & 3.6 & 4.1 \\
Proportion of labor force(\%) & 67.8 & 68.4 & 71.5 & 71.3 & 73.0 \\
Disposable income of urban residents/yuan & 6176 & 10,244 & 17,532 & 27,239 & 31,195 \\
Disposable expenditure of urban residents/yuan & - & - & $13,335.02$ & $19,742.29$ & $21,392.36$ \\
Urbanization/\% & 35.6 & 45.2 & 53 & 60.9 & 56.1 \\
\hline
\end{tabular}

Data source: the website of the National Bureau of Statistics. 3.2. Methods.

Combined with qualitative and quantitative analysis, this paper started with the internal mechanism and microstructure of the urban development system, then analyzed the relationship between the factors affecting the urban development and its dynamic behavior with the help of computer simulation technology. Taking Chongqing City as the study area, VENSIM was used to model the system dynamics.

The research steps are briefly summarized as follows. Firstly, the core elements of this research were extracted to build a conceptual model, so as to simplify and abstract the real system. Secondly, the feedbacks of each subsystem were drawn to clarify the logical relationship between system elements. Thirdly, the properties of variables were further distinguished and the whole system flow diagram was depicted with VENSIM. Fourthly, the data of Chongqing was put into the model to observe the fitting of outcomes with the actual data. The final step was to conduct scenario simulation, with the purpose of finding the variables sensitive to policies.

\subsection{Data Collection}

In order to have an intuitive understanding of the current situation of the public housing supply in Chongqing, the semi-structured interviews and field surveys were conducted to investigate the public rental housing (PRH) projects in Chongqing. All experience materials are from interviews with residents, management departments, researchers and other participants involved in the public rental housing projects, as well as a large number of materials in the form of texts, including policy documents issued by the government and news media reports. In the quantitative analysis, the data was mainly collected from the annual data of urban economic and social development in Chongqing statistical yearbook, and the network of Chongqing public rental housing information websites. Since the data 
available for one of the key variables (land use area) in the quantitative analysis can only be traced back to 2002, data from 2002 to 2017 were collected.

\section{System Dynamics Model for Urban Development}

\subsection{Conceptual Model}

The conceptual model based on the classic Three-sector Model and Urban Dynamics Model is displayed as Figure $1[34,47]$. The logic of this model is to simplify the urban system into three subsystems, including population subsystem, economy subsystem and housing subsystem. The joint efforts of these three subsystems determine the urban dynamics. Then, the housing subsystem is specified to highlight the public housing that we are interested in this research.

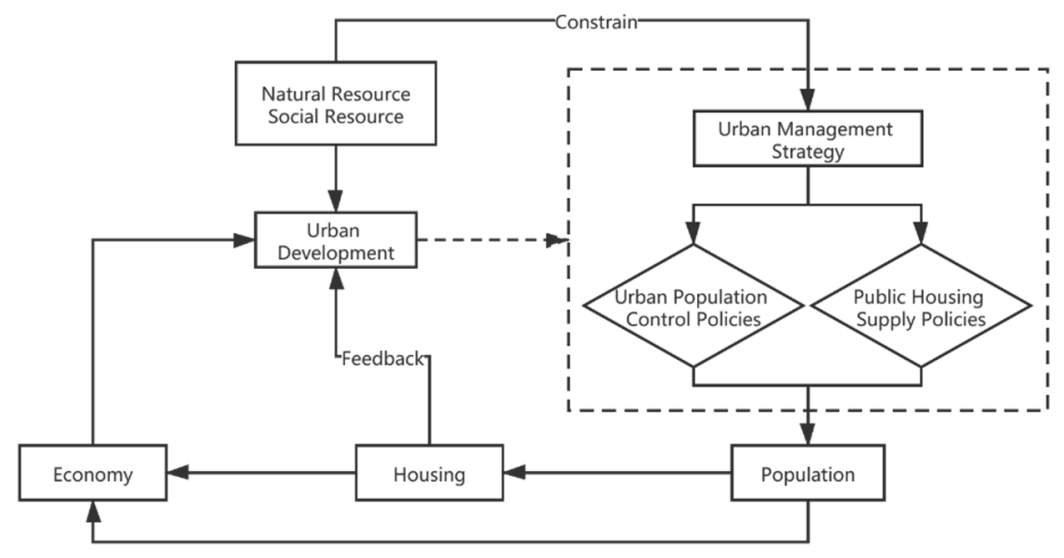

Figure 1. Urban development conceptual model.

Municipal governments are the main body of housing construction, and have full initiative in the implementation. Therefore, the formulation of public housing supply policies is supposed to be coherent to the framework of the urban management strategy. In other words, the policy content mirrors the orientation of the city, which is the reason to introduce the urban management strategy into this model. In the model, the urban management strategy consists, briefly, of urban population control policies and public housing supply policies. The former aims to limit the growth of urban population, while the latter is to guide the change of urban housing structure. The model will be used to simulate the impact of public housing supply on urban growth, and the urban population control policies and public housing supply policies will be used as the devices for regulation to simulate the dynamics of urban system under the combination of different policies.

\subsection{Feedbacks in the Model}

The model composed by three subsystems depicts the urban development system, in which the three subsystems are closely interdependent and constrained mutually. If these three subsystems are coherent with each other in the entire urban system, the city is considered in balance. In this state, the city is stable and does not grow. According to the basic economic theory, the quantity of urban products (including goods and services) first depends on the demand of urban output [34]. The sale of exported products is determined by the fluctuating prices of the same goods exported by other cities or regions. Therefore, the total urban output demand is a minus function of the price of local products. It is assumed that there is no substitution-effect between real estate and labor, so a fixed number of real estate and labor is required for any unit of output. The unit output cost of a business is the annual cost of using real estate and labor, and the differences of these two factors in cities vary local production costs.

In the case of urban growth caused by supply, when the price of goods and services reduces, the quantity increases, followed by the reduction of wage of labor force and the increase of employment. 
Furthermore, the demand of real estate increases, resulting in the increase of rent [48]. The interaction among the key elements in the system forms multiple feedbacks that affect urban development. Next, it will be decomposed into three subsystems for further analysis.

\subsubsection{Feedbacks in the Population Subsystem and Economy Subsystem}

There are two major feedback loops in the population subsystem (Figure 2). One of them carves the relationship between population and housing. Population inflows lead to overcrowding, which reduce the attraction to migrants, so as to reduce population growth in the future. The other carves the relationship between labor and business. As the population inflows, the competition for jobs becomes fierce, and the difficulty of employment will reduce the attraction to the population, so it also has a negative effect on the population growth.

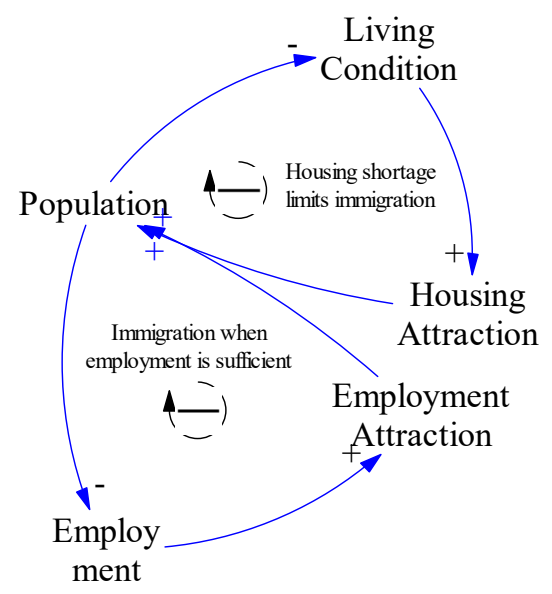

Figure 2. Feedback loops in the population subsystem.

Similarly, there are two major feedback loops in the economy subsystem (Figure 3). One of them depicts the relationship between business and labor force. The increase of business provides more jobs, which also means more demand for labor. If there is no increase in the number of labor, the demand for labor will not be met, which in turn will inhibit the growth of business. The other depicts the relationship between business and land. With the increase of business, the construction land needed will also increase. The difficulty of acquiring land for construction will gradually increase, thus limiting the increase of business.

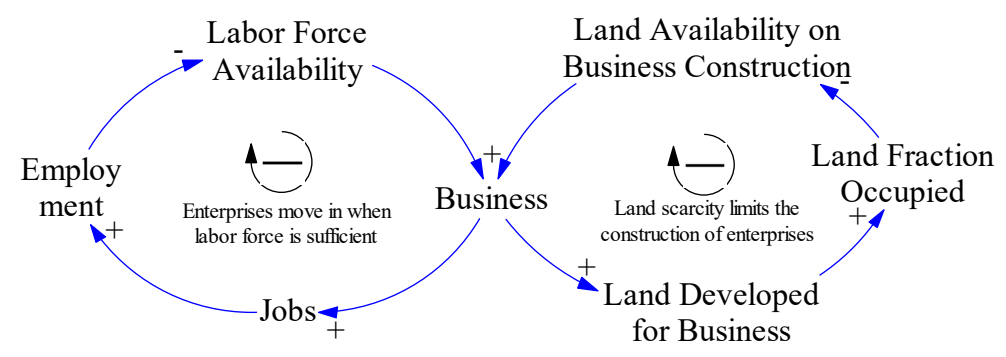

Figure 3. Feedback loops in the economy subsystem.

\subsubsection{Feedbacks in the Housing Subsystem}

Due to the specific interest in public housing, in the housing subsystem, the total housing is divided into commodity housing and public housing. There are three major feedback loops in the housing subsystem (Figure 4). One of them describes the relationship between housing and population. As mentioned in the population subsystem previously, insufficient living conditions caused by population growth lead to new housing construction, thus increasing the number of houses and improving living conditions. The second is to describe the relationship between housing and 
business. Both housing construction and business construction need to obtain construction land, so they are competitive in land use. Because of the immovability and non-renewability of the land, it is more and more difficult to obtain the construction land needed for new housing, which limits the increase of housing construction. The third is to describe the relationship between public housing and living conditions. With the improvement of living conditions year by year, the requirements of public housing will also be improved. Accordingly, the construction of public housing will also be increased, so the total amount of increased housing will further improve living conditions and form a positive feedback structure.

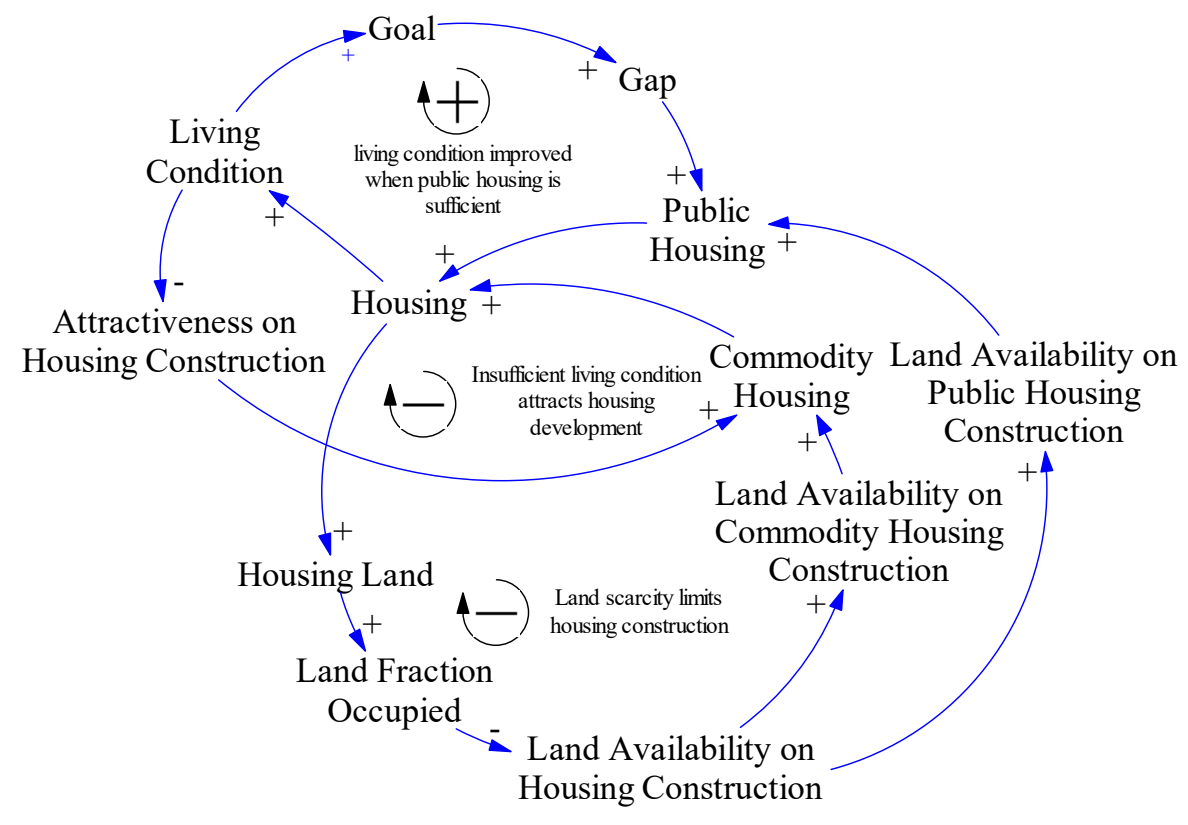

Figure 4. Feedback loops in the housing subsystem.

\subsection{Flow Diagram and Variables}

The flow diagram of the simplified urban development system is exhibited in Figure 5. The variables in the flow diagram are listed in the Appendix A.

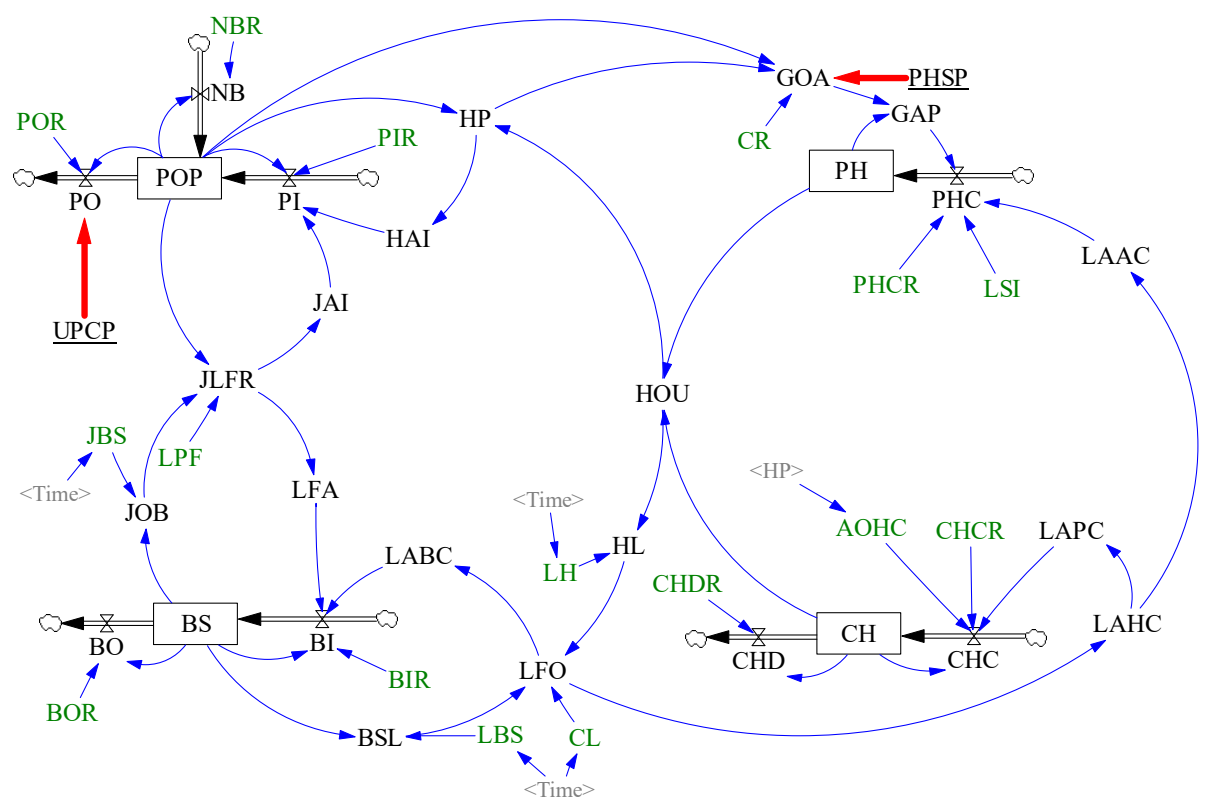

Figure 5. Simplified urban development system. 
One of the critical variables in this model is House per Person, which is the auxiliary variable as a linkage between the population subsystem and the housing system. It represents the living condition and is the key index to simulate the policy effect in the system. It is not only related to the number of commodity housing and public housing, but also affects the migration of population. Figure 6 provides the variables and their causal links related to this core variable in the system.

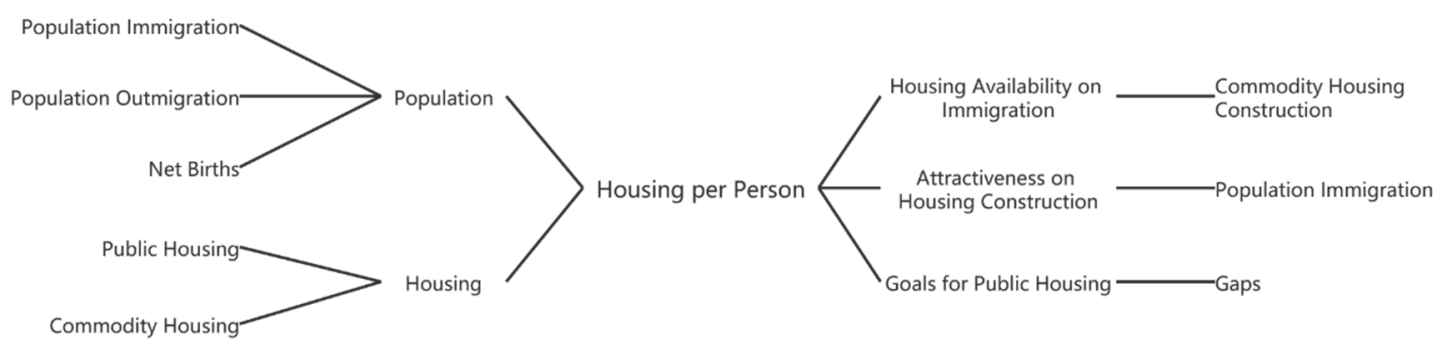

Figure 6. Causal analysis tree for Housing per Person.

From the dynamic of Housing per Person, we can assess the phase of urban development (Table 2). At the beginning of urban development, the number of population and housing is increasing rapidly, and the living condition is also improved. When the urban development keeps in balance, the population and housing quantity are stable, and the living condition also keeps stable. There are more and more people living in cities and yet new housing construction has failed to keep pace with the population growth; therefore, the living conditions begin to deteriorate and become crowded. However, when the employment situation in the city is terrible and people move out in large numbers, the housing will not be demolished because of its durability, but will be vacant, resulting in the increase of Housing per Person, statistically. It should be noted that these are broadly categorized as four stages, which are only suitable for the division of cities themselves. Different cities, even if the Housing per Person is the same, will be in different stages of development with heterogeneous housing structures and conditions.

Table 2. The relationship between urban development stages and Housing per Person.

\begin{tabular}{cccc}
\hline Urban Development Stages & Population Number & Housing Number & Housing per Person \\
\hline Growth & $\nearrow$ & $\nearrow$ & $\nearrow$ \\
Balance & $\rightarrow$ & $\rightarrow$ & $\rightarrow$ \\
Crisis & $\nearrow$ & $\rightarrow$ & $\searrow$ \\
Decline & $\searrow$ & $\rightarrow$ & $\nearrow$ \\
\hline
\end{tabular}

\section{Scenario Simulation}

\subsection{The Central Area of Chongqing}

Chongqing is one of the four municipalities directly under the central government, as well as the largest city in China. Located in Southwest China, Chongqing is an important industrial and commercial city, of which the economic foundation is manufacturing industry. As the area of Chongqing reaches the scale of provincial region, it is not scientific to measure the whole administrative region, so the central area, illustrated in Figure 7, is often used in planning and economic statistics. Public housing projects are also concentrated in this area.

The central area of Chongqing contains a floating population of more than 7 million, which is one of the main residence areas of the floating population in China. Since 2010, the floating population in Chongqing has increased significantly, and then maintained stable and sustained growth. To a certain degree, the growth of population benefits from the public housing projects were planned in 2009 and launched in 2010. The floating population is attracted to the central area by employment. The large-scale public housing built in the central area provides a way to solve the living problem of 
the floating population. It can be seen that, in line with the laws discovered in the eastern coastal cities [14], the increase of public housing in Chongqing has promoted the inflow of population.

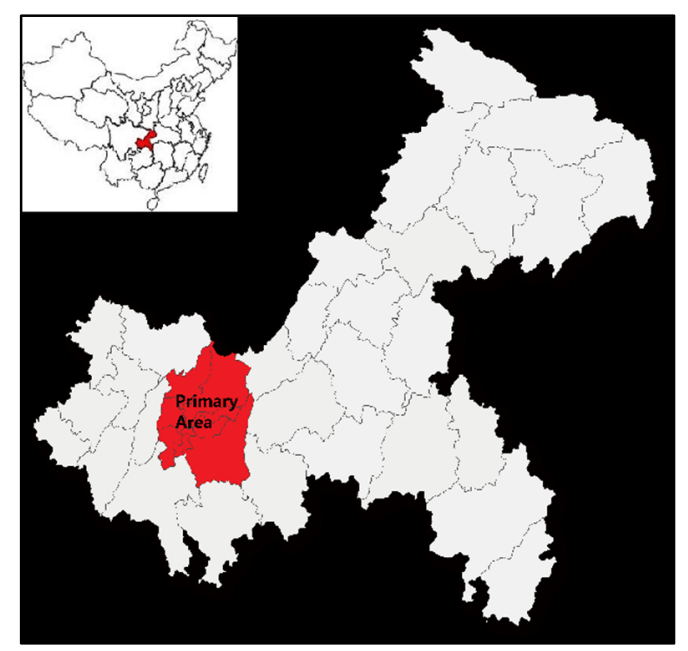

Figure 7. The map of Chongqing and its central area.

The cost of living in Chongqing is at a low level in big cities, and the price of commodity housing has been lower than the national average price. After 2011, the price of commodity housing in Chongqing fluctuated little. In particular, since 2014, the national housing prices have continued to rise, while Chongqing's housing prices have remained stable.

\subsection{Results}

Taking Chongqing as the research area, data from 2002 to 2017 are used for parameter design and model testing, and then the system dynamics from 2018 to 2050 are simulated. Figure 8 displays the basic simulation results of the overall trend of housing, population and economy from 2002 to 2050. During the simulation period, the number of housing, population and enterprises are growing continuously, among which the growth rate of enterprises and population is basically stable, while the growth rate of housing has obvious changes. The growth rate of housing in the early stage is quite fast, while slows down significantly in the later stage.
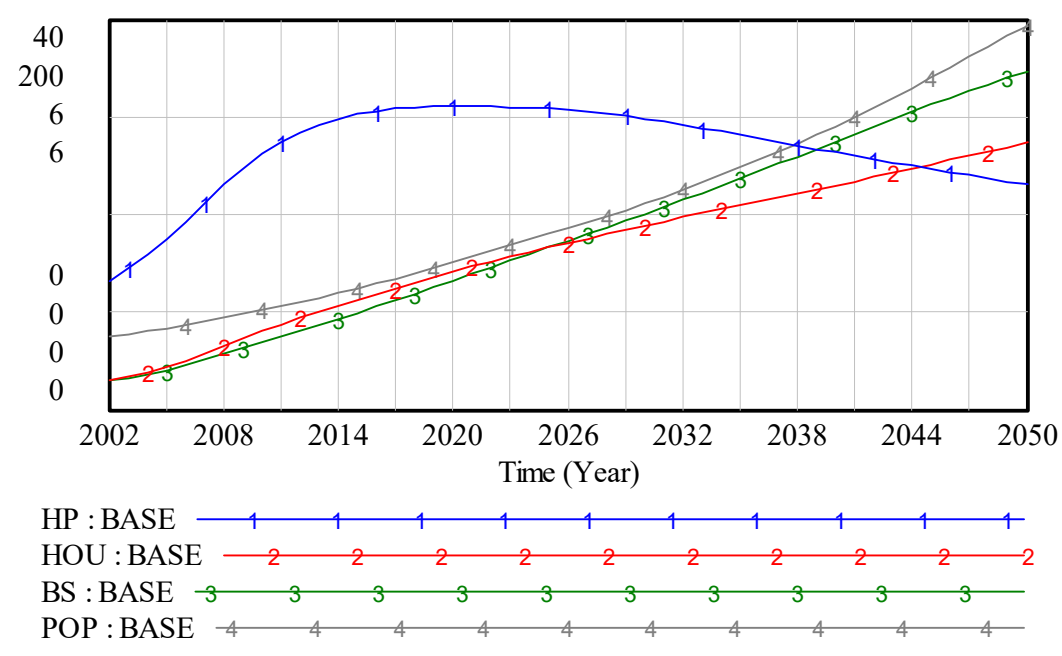

Figure 8. Overall system dynamics.

Accordingly, the Housing per Person has gone through three stages in the time line: first, from 2002 to 2014 , as the growth rate of housing quantity exceeds the growth rate of population, the Housing 
per Person has increased rapidly; then, from 2014 to 2026, the growth rate of housing quantity and population has converged, making the Housing per Person basically stable; finally, from 2026 to 2050. The growth rate of housing slows down. Although the number of housing still keeps growing, it cannot keep up with the growth of population, so the Housing per Person has declined significantly.

It is worth noting that the Housing per Person began to decrease in 2026, which is an inflection point in the change of living conditions, dropping a hint of the germination of the informal housing phenomenon in the process of urbanization [49]. The residents in the city have the desire to pursue a better life, will strive to improve living conditions, and the housing area of the original residents in the city will be maintained or increased. Therefore, the main contributor to the decrease of the Housing per Person is the new urban population. To work or study in a city with a large population and high house prices means a compromise on living space and environment, where affordable housing is difficult to find not only for low-income people, but even for middle-income people, such as young researchers [50].

The goal of system dynamics modeling is to observe the behavior of the system, so the model check mainly estimates the correctness and validity of simulation results from whether it conforms to the purpose of modeling. In order to modify the parameter setting and improve the model structure, the units check, integral error check, parameter sensitivity check and model consistency check are carried out. The model is stable and has passed various checks.

\subsection{Policy Simulation Experiment to Promote Urban Inclusive Growth}

There are two main policy instruments to deal with the possible housing crisis during urbanization. First, from the aspect of population control, we should evacuate the population of big cities, reduce the congestion of resource utilization, guide the reasonable layout of cities, and improve the quality of urban development. Second, from the aspect of housing supply, we should provide more public housing and improve the living conditions of urban inhabitants, especially the migrant workers.

Next, Chongqing was selected as the research area. The model of the urban development system was applied to carry out simulation experiments on the implementation of these two policies, and to analyze the implementation effect of these two policies on each subsystem of urban development, so that a comparison of the impact of the two policies on urban inclusive growth was launched.

\subsubsection{Population Control Policy Simulation}

The meaning of urban population control policy in the system is to increase population outflow. Whether the population is forced to move out by means of control or guided by means of incentive, its policy purpose is to reduce the total population in the city. The population control policy variables were set as 1.5 (UPCP1) and 2 (UPCP2) since the Housing per Person entered the stable period in 2014. BASE was the control group with the policy value as 1. Following test results were obtained (Figure 9).

As shown in Figure 9, population control policy has had a direct effect on the reduction of the urban population. Under the policy effect of 1.5 , the total urban population will be reduced to half of the control group by 2050. If the policy intensity is doubled, the total population will even decline. Accordingly, the housing condition has also changed. Under the two policy intensities, the Housing per Person has not decreased. It can be seen that the effect of urban population control policy is significant.

However, the population control policy has had a negative impact on the economic system. Compared with the control group, the number of business decreased significantly. When the urban population control policy is intense, the economic system will stagnate. The key impact on the economic system is the labor force. A labor force shortage reduces the attraction of enterprises to move in. As a result, population control strategy is not conducive to inclusive urban growth to some extent. 


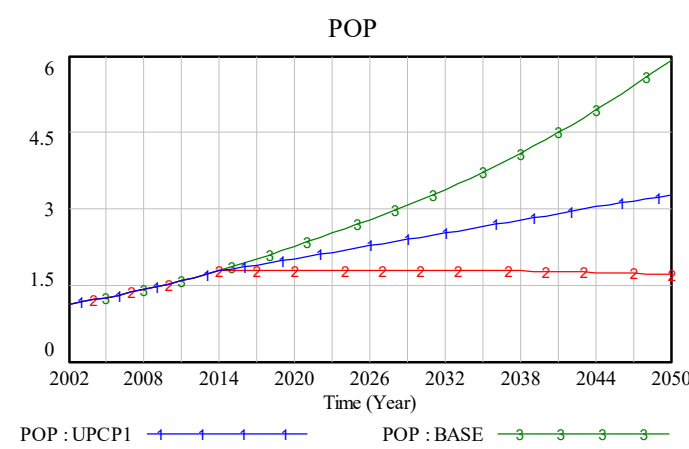
POP :UPCP2 $\begin{array}{lllll}4 & 2 & 2 & 2\end{array}$

BS

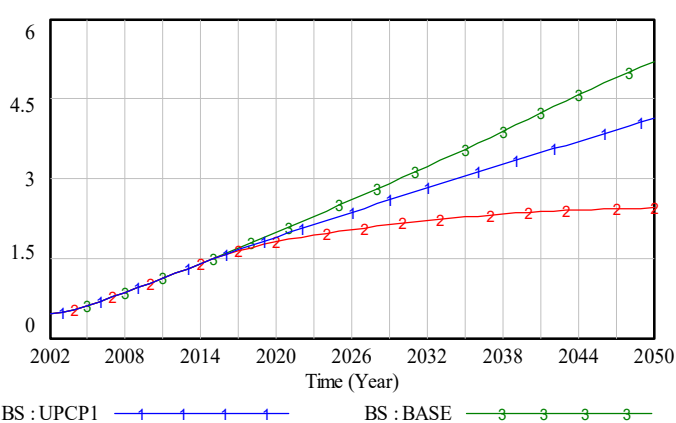

BS : UPCP2
BS : BAS

Figure 9. Simulation results of urban population control policy.

JLFR: UPCP1

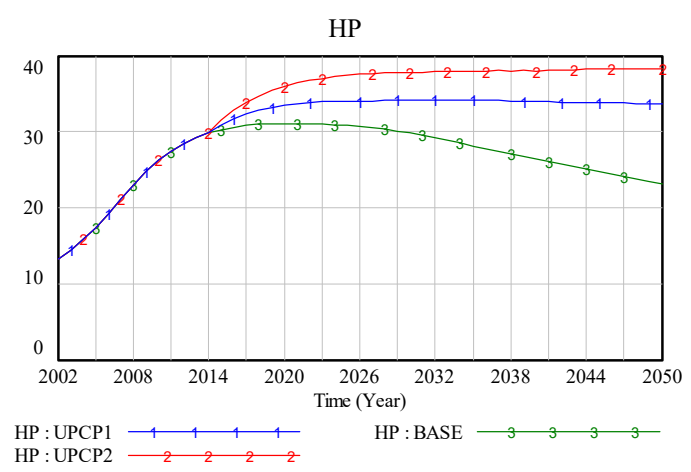

JLFR

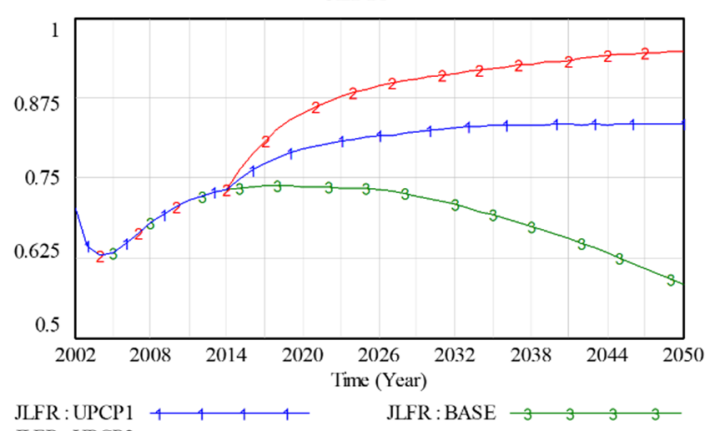

\section{(ear)}

.

\subsubsection{Public Housing Supply Policy Simulation}

The meaning of public housing supply policy is to raise the goal of public housing construction. The difference of policy intense affects the housing construction speed towards differentiated goals. The public housing supply policy variables were set as 3 (PHSP3) and 5 (PHSP5) since the Housing per Person entered the stable period in 2014. BASE was the control group with the policy value as 1 . The following test results were obtained (Figure 10).
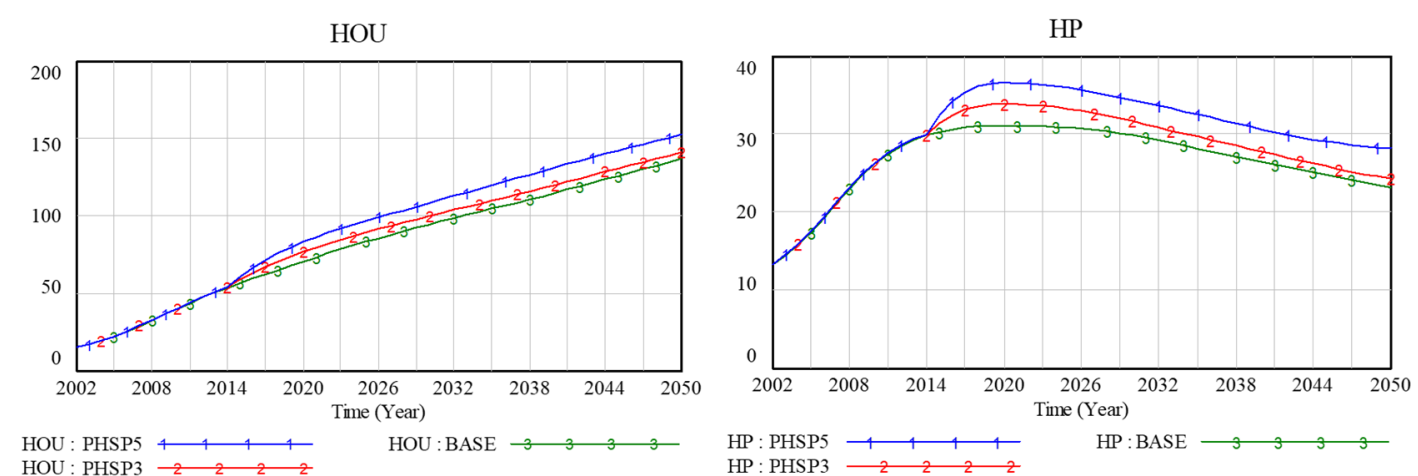

Figure 10. Simulation results of public housing supply policy.

As shown in Figure 10, the public housing supply policy has the effect of increasing the total amount of housing, but the increase is not significant. During the whole test period, the increase of the total housing stock caused by the strengthening of the two policies is only 3\% and $11 \%$. From the perspective of the trend of living condition, although the public housing supply policy has enhanced the living conditions, in the long run, it is still unable to avoid the decline of Housing per Person. 


\subsubsection{Combination Simulation}

Considering the advantages of the combination of the two policies, the combination strategy of urban population control policy and urban housing security policy (UPCP + PHSP) is designed, in which the value of UPCP is 1.5, the value of PHSP is 3 , and the implementation of the combination policy is started from different time points. The simulation results are as follows (Figure 11).
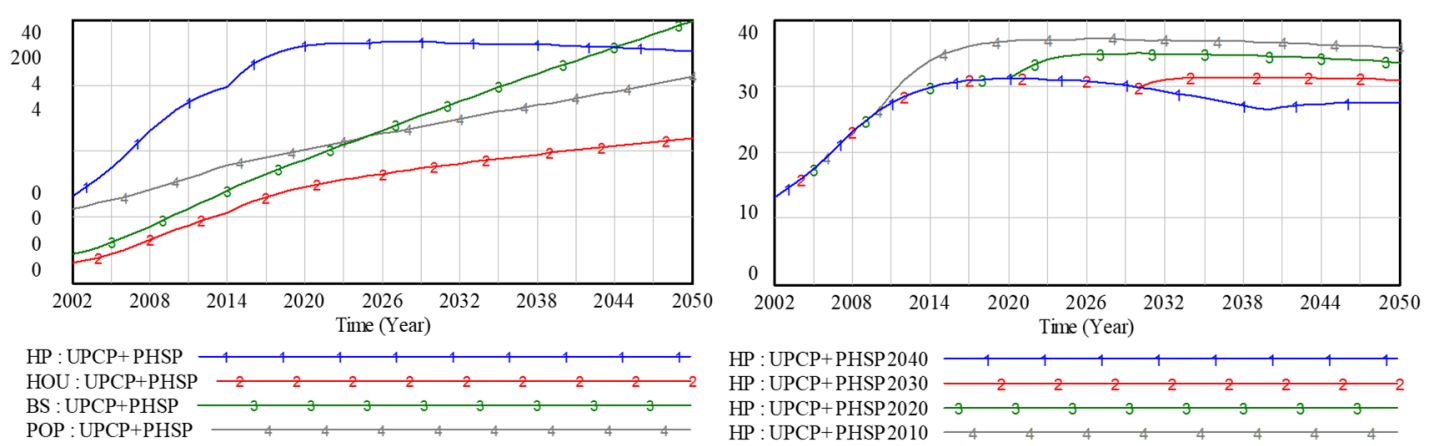

Figure 11. Simulation results of combined policy.

As shown in Figure 11, under the combination policy, the growth of total population has been effectively controlled, while the economic system has not been damaged, but maintained rapid development. After the Housing per Person reaches the maximum value around 2030, it is also basically stable. Obviously, the simulation effect of the combined policy is better than that of any single policy, which promotes the overall development of the urban system to a balanced state. The starting time of intervention also has a significant impact on the policy effect. Before the Housing per Person began to decline, policy intervention could improve the living conditions.

\section{Discussion}

The application of simulation models to evaluate urban growth policies has been commonplace since the 1960s, but constructing empirical models to study the public housing supply with urban growth management is not easy to achieve, primarily because the models have to be able to shed light on some of the key policy issues [51]. In this study, we try to compare groups of policy experiments to get some inspiration. It should be noted that the simulation was based on the assumption that the current population change rate and construction technology had not changed significantly. In the future, if there is a significant change in population or a major breakthrough in construction technology, there will be a large gap between the simulation results and the real-world development trend.

The simulation experiment has brought important enlightenments to the formulation of public housing supply policy: One is the balance between population and housing; The other is the balance between commodity housing and public housing. Through the comparison of the three above groups of policy simulation experiment results, it can be seen that the urban population control policy and public housing supply policy have their own advantages and disadvantages in the implementation effect, and their impact on urban growth are based on different mechanisms. It is found that the improvement of living conditions is in favor of the citizenization of the migrants, while the increase of enterprises helps the development of industry and the employment growth is also conducive to the improvement of the living standards of urban residents.

The experimental effect of public housing supply policy is not as significant as that of urban population control policy, but it actually contains the change of housing structure. As Lv and Chen argued, the increase of public housing in the proportion of housing structure plays an important role in avoiding excessive commercialization of housing market and promoting housing to return to the residential property [12]. However, we also need to take into account that, under the government led public housing construction mode, the speed of public housing construction is also subject to 
government finance and other factors [52]. A large number of public housing construction challenges the long-term maintenance and management, so it may also bring hidden dangers to the housing market.

In the simulation, it was found that the cost of public housing expansion was the slowdown of the growth rate of commercial housing, which means the growth rate of total housing was small, that is, the so-called crowd-out effect [13]. Public housing and commodity housing construction are restricted by residential land planning at the same time. Especially, when the developable residential land is scarce, there is a competition between housing construction and commodity housing construction in land availability $[24,26]$. If priority is given to ensuring the land for public housing construction, it will aggravate the difficulty of land supply for commodity housing construction [25].

In real life, the differences between the two policies are also included in the feasibility of the policies. The experimental effect of urban population control policy is more direct, but it will run into the obstacles of social factors in reality [43]. In the specific policy formulation and implementation processes, as long as the question —who should be guided to move out?-is considered, political, ethical and moral issues will be involved. The correct policy objectives, under the wrong implementation measures, will not only fail to achieve the desired results, they will intensify social contradictions.

\section{Conclusions}

This paper discussed the impact mechanism of public housing supply and urban population control on urban growth, and carried out policy simulation experiments. Based on the influence mechanism of housing supply on urban growth, the urban system is divided into three subsystems: population, economy and housing. By analyzing the internal and mutual influence of the three sub-systems, the causal relationship of urban growth system is observed in depth. Then, the urban growth system model was constructed, and the policy simulation experiments under different urban development strategies were carried out. The policies to deal with urban housing crisis include population control policy and public housing supply policy. Taking Chongqing as the research area, through the simulation of the real system it was found that the combination of population control policy and public housing supply policy can more effectively cope with the possible urban housing crisis under the long-term trend, and promote urban inclusive growth.

In light of the simulation of the real urban development system, it was observed that the urban living conditions form an inverted U-shaped curve. In the long run, the housing supply is limited by the land supply in a certain location, so there will be a turning point in the improvement of living conditions and the life of the poor will get worse. Therefore, in line with the basic law of urban development, urban growth management (especially land use planning) should lead housing policies to be more equitable. In other words, guided by housing demand, land use planning should be optimized and to promote the coordinated development of housing supply and urban population growth.

This study theoretically analyzed the relationship between the public housing supply and urban growth management, and provided a reference for the development of public housing policies in China and many other developing countries in the process of urbanization. The analysis of this study focused on the public rental housing, while - since the history of vigorously promoting public rental housing in China is only more than ten years-the effect of policy needs to be further observed in the long-term development in the future. It is worth noting that the influence of policy environment is complex; there are no uniform housing polices which can be applied to various urban housing markets. Therefore, according to different urban development stages, it is of great significance to further carry out multi-case comparative studies.

Author Contributions: Conceptualization, W.W. and Y.W.; methodology, Y.W.; data curation, W.W.; writing-original draft preparation, W.W.; writing-review and editing, Y.W.; funding acquisition, W.W. and Y.W. All authors have read and agreed to the published version of the manuscript.

Funding: The research was funded by the Philosophy and Social Science of Ministry of Education of China, grant number 20YJC630147; the Beijing Key Laboratory of Megaregions Sustainable Development Modelling, Capital University of Economics and Business, grant number MCR2019BS02; the National Natural Science Foundation of 
China, grant number 71874155 and the Key Project of Philosophy and Social Science of Ministry of Education of China, grant number 18JZD033.

Conflicts of Interest: The authors declare no conflict of interest.

\section{Appendix A}

Table A1. The variables in the flow diagram.

\begin{tabular}{|c|c|c|}
\hline Subsystem & Variable & Variable Abbreviation \\
\hline \multirow{8}{*}{ Population subsystem } & Population & POP \\
\hline & Net Births & NB \\
\hline & Net Birth Rate & NBR \\
\hline & Population Outmigration & $\mathrm{PO}$ \\
\hline & Population Outmigration Rate & POR \\
\hline & Population Immigration & PI \\
\hline & Population Immigration Rate & PIR \\
\hline & Labor Participation Fraction & LPF \\
\hline \multirow{11}{*}{ Economy subsystem } & Business Structures & BS \\
\hline & Business Outmigration & $\mathrm{BO}$ \\
\hline & Business Outmigration Rate & BOR \\
\hline & Business Immigration & BI \\
\hline & Business Immigration Rate & BIR \\
\hline & Labor Force Availability & LFA \\
\hline & Jobs & JOB \\
\hline & Jobs per Business Structure & JBS \\
\hline & Business Structure Land & BSL \\
\hline & Land per Business Structure & LBS \\
\hline & Land Availability on Business Construction & LABC \\
\hline \multirow{19}{*}{ Housing subsystem } & Housing & HOU \\
\hline & Public Housing & $\mathrm{PH}$ \\
\hline & Public Housing Construction & PHC \\
\hline & Public Housing Construction Rate & PHCR \\
\hline & Land Supply Intensifier & LSI \\
\hline & Goal & GOA \\
\hline & Coverage Rate & $\mathrm{CR}$ \\
\hline & Gap & GAP \\
\hline & Commodity Housing & $\mathrm{CH}$ \\
\hline & Commodity Housing Demolition & $\mathrm{CHD}$ \\
\hline & Commodity Housing Demolition Rate & CHDR \\
\hline & Commodity Housing Construction & $\mathrm{CHC}$ \\
\hline & Commodity Housing Construction Rate & CHCR \\
\hline & Land Availability on Commodity Housing Construction & LACC \\
\hline & Land Availability on Housing Construction & LAHC \\
\hline & Land Availability on Public Housing Construction & LAPC \\
\hline & Attractiveness on Housing Construction & $\mathrm{AOHC}$ \\
\hline & Housing Land & HL \\
\hline & Land per House & $\mathrm{LH}$ \\
\hline \multirow{6}{*}{ Linkage subsystem } & House per Person & $\mathrm{HP}$ \\
\hline & Jobs to Labor Force Ratio & JLFR \\
\hline & Land Fraction Occupied & LFO \\
\hline & Construction Land & CL \\
\hline & Housing Availability on Immigration & HAI \\
\hline & Job Availability on Immigration & JAI \\
\hline \multirow{2}{*}{ Urban management strategy } & Urban Population Control Policies & UPCP \\
\hline & Public Housing Supply Policies & PHSP \\
\hline
\end{tabular}

\section{References}

1. Huang, L.; Yan, L.; Wu, J. Assessing urban sustainability of Chinese megacities: 35 years after the economic reform and open-door policy. Landsc. Urban Plan. 2016, 145, 57-70. [CrossRef]

2. Ye, Z.; Qian, L.; Na, Z. Financial Development, Urbanization, and Urban-Rural Income Disparity: Evidence Based on Chinese Provincial Data. Mod. Econ. 2018, 9, 31-60. [CrossRef] 
3. Cohen, B. Urban Growth in Developing Countries: A Review of Current Trends and a Caution Regarding Existing Forecasts. World Dev. 2004, 32, 23-51. [CrossRef]

4. Ding, C.; Duan, X.; Niu, Y. Megacities in the World: Growth, Challenges and Appreciation. Urban Plan. Int. 2015, 30, 1-13.

5. Roy, A. Slumdog Cities: Rethinking Subaltern Urbanism. Int. J. Urban Reg. Res. 2011, 35, 223-238. [CrossRef]

6. Liu, X.; Chen, Z.; Lu, M. Social integration and economic growth: Endogenous policy changes of urbanization and urban development. J. World Econ. 2010, 6, 60-80.

7. Li, Y.; Wang, R. Urban inclusiveness and the social inclusion of internal migrants in China. China Popul. Resour. Environ. 2017, 27, 146-154.

8. Wang, W.; Wu, Y.Z.; Sloan, M. A framework \& dynamic model for reform of residential land supply policy in urban China. Habitat Int. 2018, 82, 28-37.

9. Joint research group of the development research center of the State Council and the World Bank. China: Toward an efficient, inclusive and sustainable urbanization. Manag. World 2014, 4, 5-41.

10. Zou, G.; Chau, K. Determinants and sustainability of house prices: The case of Shanghai, China. Sustainability 2015, 7, 4524-4548. [CrossRef]

11. Gan, X.; Zuo, J.; Chang, R.; Li, D.; Zillante, G. Exploring the determinants of migrant workers' housing tenure choice towards public rental housing: A case study in Chongqing, China. Habitat Int. 2016, 58, 118-126. [CrossRef]

12. Lv, P.; Chen, H. On the policy orientation based on the relationship between commercial housing and affordable housing. Soc. Sci. Beijing 2014, 11, 61-67.

13. Yu, X.; Zeng, H.; Ren, T. Crowd-out effect of government-subsidized housing to commercial housing market: Theoretical and empirical analysis. Acad. Mon. 2015, 47, 57-65.

14. Mao, F.; Wang, J. Can indemnificatory housing promote population flow? - A gravity model analysis based on the inter-provincial population flow. East China Econ. Manag. 2016, 30, 86-95.

15. Wu, Y.; Wang, W. Research on the coordination mechanism of affordable housing and urban economic growth. J. Hehai Univ. 2016, 18, 27-33.

16. Wetzstein, S. The global urban housing affordability crisis. Urban Stud. 2017, 54, 3159-3177. [CrossRef]

17. Driant, J. The Main Issues of Social Housing Policies in Europe and in France. Urban Plan. Int. 2009, 4, $22-27$.

18. Moore, R. Slow Burn City: London in the Twenty-First Century; Picador: London, UK, 2016.

19. Blokland, T. "You got to remember you live in public housing": Place-Making in an American housing project. Hous. Theory Soc. 2008, 25, 31-46. [CrossRef]

20. Madden, D.; Marcuse, P. Defense of Housing; Verso: London, UK; New York, NY, USA, 2016.

21. Rosen, K.; Madelyn, R. Increasing homeownership in urban China: Notes on the problem of affordable. Hous. Stud. 2000, 15, 77-89. [CrossRef]

22. Hui, C.M.; Leung, Y.P.; Yu, K.H. The impact of different land-supplying channels on the supply of housing. Land Use Policy 2014, 39, 244-253. [CrossRef]

23. Zou, Y. Contradictions in China's affordable housing policy: Goals vs. structure. Habitat Int. 2014, 41, 8-16. [CrossRef]

24. Wong, G. Vertical cities as a solution for land scarcity: The tallest public housing development in Singapore. Urban Des. Int. 2004, 9, 17-30. [CrossRef]

25. Zheng, S.; Zhang, Y.; Zhang, S.; Long, Y.; Du, L. The Evaluation Method of Affordable Housing Site Selection Based on the Trade-off between Social Benefit and the Opportunity Cost of Land: A Quantitative Analysis Based on the Differences in Preferences of Residential Location Choice between High-income and Low-income Residents. Manag. Rev. 2016, 8, 3-11.

26. Shamsuddin, S.; Vale, L.J. Lease it or lose it? The implications of New York's Land Lease Initiative for public housing preservation. Urban Stud. 2017, 54, 137-157. [CrossRef]

27. Ding, C. Growth of World Megacities: Trend, Challenge, Growth Policy and Effectiveness; China Architecture \& Building Press: Beijing, China, 2015.

28. Kuznets, S. Economic growth and income inequality. Am. Econ. Rev. 1955, 45, 1-28.

29. Alesina, A.; Perotti, R. Income distribution, political instability, and investment. Eur. Econ. Rev. 1996, 40, 1203-1228. [CrossRef]

30. Benner, C.; Pastor, M. Just Growth: Inclusion and Prosperity in America's Metropolitan Regions; Routledge: Oxon, UK; New York, NY, USA, 2012. 
31. Lu, M. Great State Needs Bigger City; Shanghai People's Publishing House: Shanghai, China, 2016.

32. Kemeny, J. From Public Housing to the Social Market: Rental Policy Strategies in Comparative Perspective; Routledge: London, UK, 1995.

33. Barr, N. The Economics of the Welfare State; Stanford University Press: Redwood, CA, USA, 1998.

34. Dipasquale, D.; Wheaton, W. Urban Economics and Real Estate Markets; Englewood Cliffs: Prentice-Hall, NJ, USA, 1996.

35. Glaeser, E.L.; Gyourko, J.; Saks, R.E. Urban growth and housing supply. J. Political Econ. 2006, 6, 71-89. [CrossRef]

36. Fu, Y.; Zheng, S.; Liu, H. Population Growth across Chinese Cities: Demand Shocks, Housing Supply Elasticity and Supply Shifts. Available online: https://ssrn.com/abstract=1153022 or http://dx.doi.org/10.2139/ ssrn.1153022 (accessed on 1 July 2008).

37. Long, F.; Guo, M. Research on the impact of land supply on urban growth in China. Urban Dev. Stud. 2009, 6, $83-87$.

38. Zheng, S.; Liao, J.; Ren, R.; Cao, Y. Housing policy for migrant workers and economic growth. Econ. Res. J. 2011, 2, 73-86.

39. Wang, X. A Study on the Impact Assessment of Public Housing Residential District on Urban Social Space. Ph.D. Thesis, Southeast University, Dhaka, Bangladesh, 2016.

40. Tusting, L.S.; Bisanzio, D.; Alabaster, G.; Cameron, E.; Cibulskis, R.; Davies, M.; Flaxman, S.; Gibson, H.S.; Knudsen, J.; Mbogo, C.; et al. Mapping changes in housing in sub-Saharan Africa from 2000 to 2015. Nature 2019, 568, 391-394. [CrossRef]

41. Berry, M. Why is it important to boost the supply of affordable housing in Australia-And how can we do it? Urban Policy Res. 2003, 21, 413-435. [CrossRef]

42. Quigley, J.M.; Raphael, S. Is Housing Unaffordable? Why Isn't It More Affordable? J. Econ. Perspect. 2004, 18, 191-214. [CrossRef]

43. Tao, L.; Hui, E.C.M.; Wong, F.K.W.; Chen, T. Housing choices of migrant workers in China: Beyond the Hukou perspective. Habitat Int. 2015, 49, 474-483. [CrossRef]

44. Bloom, N.D.; Umbach, F.; Vale, L.J. Public Housing Myths: Perception, Reality, and Social Policy; Ithaca \& Cornell University Press: London, UK, 2015.

45. Popkin, S.J. No Simple Solutions: Transforming Public Housing in Chicago; Rowman \& Littlefield: Lanham, MD, USA, 2016.

46. Aliprantis, D.; Hartley, D. Blowing it up and knocking it down: The local and city-wide effects of demolishing high concentration public housing on crime. J. Urban Econ. 2015, 88, 67-81. [CrossRef]

47. Forrester, J. Urban Dynamics; MIT Press: Cambridge, MA, USA, 1969.

48. Tsai, C. Housing affordability, self-occupancy housing demand and housing price dynamics. Habitat Int. 2013, 40, 73-81. [CrossRef]

49. Zhao, P. Informal Suburbanization in Beijing: An Investigation of Informal Gated Communities on the Urban Fringe. Habitat Int. 2018, 77, 130-142. [CrossRef]

50. Woolston, C. A home on a budget. Nature 2017, 547, 247-249. [CrossRef]

51. Batty, M. The New Science of Cities; MIT Press: Cambridge, MA, USA, 2013.

52. Xu, H.; Zhou, Y. Public housing provision and housing vacancies in Japan. J. Jpn. Int. Econ. 2019, 53, 1-14. [CrossRef]

(C) 2020 by the authors. Licensee MDPI, Basel, Switzerland. This article is an open access article distributed under the terms and conditions of the Creative Commons Attribution (CC BY) license (http://creativecommons.org/licenses/by/4.0/). 